\title{
Factors Accountable for Non-Participation in the Stock Market: Identification and Ranking
}

\author{
Arpita Sharma ${ }^{1}$, Akanksha Goel ${ }^{2}$, Shailesh Rastogi ${ }^{3}$ and Venkata Mrudula Bhimavarapu ${ }^{2 *}$ \\ ${ }^{1}$ Assistant Professor, Symbiosis Institute of Business Management, Symbiosis International (Deemed University), \\ Pune, India; arpita.sharma85@gmail.com \\ 2Ph.D. Scholar, Symbiosis International (Deemed University) Pune, India; \\ akanksha.goel111@gmail.com, mrudulabhimavarapu@gmail.com \\ ${ }^{3}$ Professor, Symbiosis Institute of Business Management, Symbiosis International (Deemed University), \\ Pune, India; krishnasgdas@gmail.com
}

\begin{abstract}
Non-Participation in the Stock (NPS) market is a serious concern especially with the rising burden of debt in general and NPA in particular in the Indian economy. This paper is an attempt to address the problem of NPS. Identification of factors accountable for NPS is the first step to resolve the problem. Ranking is obviously the second step so that the problem can be resolved in the sequential manner. The current study identifies: willingness to invest, cash availability, knowledge of the equity market, expectation of returns, trust on the market and risk in the market. The factors are delineated in the order of the priority. Willingness to invest in the stock market come out to be more important reason for NPS and risk in the market happens to be the least important factor in the pecking order of factors for NPS. A multi-criteria decision making tool, Analytical Hierarchical Process (AHP) is applied to set the identified factors into the order of their relevance for NPS. The findings of the study have unique attributes in terms of newer set of factors and the method of ranking them. The relevant factors for NPS identified in the current study can be responded with the appropriate change or revision in the guidelines and policies to address the problem of NPS. Moreover, one of the major implications of the study is that the factors can be taken care of in the step wise manner as compared to taking up all at the same time.
\end{abstract}

Keywords: Analytical Hierarchical Process (AHP), Equity Market, Factor Analysis, Investors, Mutual Funds

\section{Introduction}

After the introduction of financial reforms in the Indian economy in 1991, there had been good growth in the Indian capital market since then. The economic growth of any country is primarily driven by its financial markets. It facilitates mobilisation of savings from savers to borrowers, through various financial intermediaries and financial institutions. One significant unit of financial market is Equity Market. Investing in the equity market can be done either through direct investment in equity shares or through equity-based mutual funds.

Buying shares directly from equity market can be a cumbersome, time-consuming and risky process. Investing directly in the equity market requires expert knowledge and time to obtain and analyse information about the company profile, its dividend and return history, its prospects and many more (Jain \& Gangopadhyay, 2012). Thus, an investor who does not have potential information about the market can invest in mutual funds

${ }^{*}$ Author for correspondence 


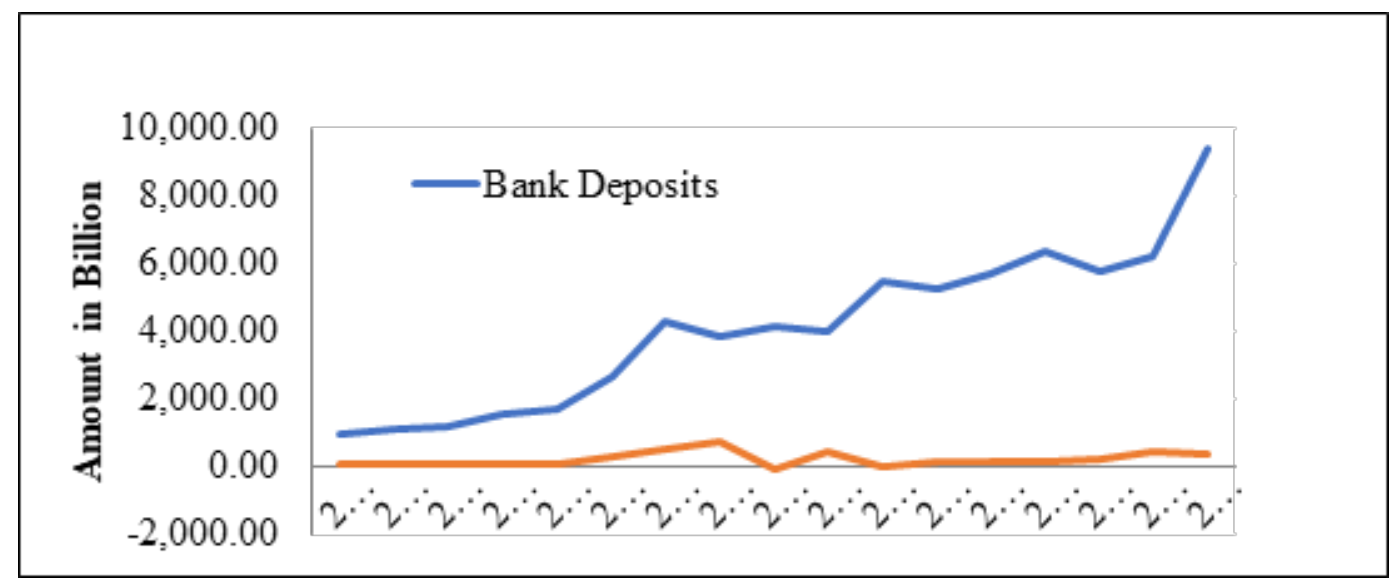

Source: RBI (2017; see table 12 ).

Figure 1. Indian household investments in bank deposits and shares and debentures.

and gain many advantages such as diversification, efficient portfolio management, liquidity and several tax benefits (Chawla, 2014).

According to a report by RBI (2017) (please see the table 12), only 10.03 per cent Indians participate actively in stock market, and this figure is extensively low as compared to the other nations, e.g. in Europe percentage participation is 26 per cent and in the USA, this figure is 49.70 per cent (Christelis, Georgarakos, \& Haliassos, 2013). Equity investment is not a popular investment choice in India. Most preferred investment avenue in India is bank fixed deposits and real estate investment (Kaur \& Kaushik, 2016). Also, according to the RBI (2017) survey households in India mobilise the majority of their savings into bank deposits rather than investing in other modes of investment (Figure 1). This suggests that India has become a nation where there is a need to motivate individuals to channelize their savings into the stock market. Thus, to broaden the equity investment (stock or mutual fund) base in India, it is essential to understand factors that drive the investment behaviour of an Indian investor. This research aims to attain such an objective.

\subsection{Consumer behaviour Theory and Behavioural Finance}

The decision making of investors to invest in a financial product can be examined under the consumer behaviour theory. Consumer behaviour model is designed to explain how the behaviour of individuals and certain factors influence consumers while making buying decisions (Engel, Kollat \& Blackwell, 1968). Solomon (1999) demonstrated that the study of consumer behaviour reveals the factors that influence an individual's choice of product. Investment in equity and equity-based mutual fund is a financial product. By considering the investment as a product and investors as consumers, it can be argued that an investment is a purchase decision which reveals the choices made by investors based on some factors. It would be illuminating to understand those factors on which investors base their decision. This knowledge would provide fund managers to develop effective investment products which could motivate investors to invest in equity and equity-based mutual funds. Thereby, a fund manager can offer better financial product which fits the need of the investor.

A recent development in financial research has clubbed together the concept of finance and consumer behaviour and coined a new term: behavioural finance (Lim, Soutar, \& Lee, 2016). However, professional investors prefer to base their decisions solely on the conventional approach such as statistical observations, technical analysis and fundamental analysis (Dimitrios, 2007). With the introduction of behavioural finance, it is observed that investment decisions are not merely based on deterministic financial theories, but also on 
the emotions and perceptions of Investors (Ritter, 2003). Thus, with the rise of choices in investment, it has become necessary to explore the factors (behavioural or nonbehavioural) that an investor considers before investing in the equity market and equity-based mutual funds. The findings of this research would facilitate to design such investment products which would accommodate to the requirements of the stakeholders in a much more efficient way.

The literature on behavioural finance concerning investor behaviour is extensive. Yet, there exists a substantial research gap concerning the relative ranking of factors that has an impact of the selection of equity funds by Indian retailers. Also, most of the previous research has been carried out on institutional investors rather than on individual investors (Rastogi, 2014). Accordingly, this research aims to narrow this gap. Rather than focusing on the reasons why there is less participation in the Indian equity market, this paper explores the factors (behavioural and financial) that are considered by an individual equity investor before investing in the Indian stock market and provide relative importance to them. Factors identified would set a benchmark for new prospective stakeholders who would want to put their money in the stock market.

\subsection{Relative Importance of Factors for an Investor}

Although, there is enormous literature on the factors influencing decision making of an investor, most of the research does not take into account the relative importance of the factors identified. Only a few attempts have been made to provide relative importance to factors (Clark-murphy \& Soutar, 2004), but none of those research took point of view of subject experts. This research work makes a novel contribution by determining the relative importance of each factor by assigning them ranks through the Analytical Hierarchical Process (AHP). Findings of previous research are solely based on the perception of investors, and no consideration is given to subject experts of the equity market. But with the introduction of AHP in our methodology, the insights of market experts are also taken into account. Market experts have valuable experience of the equity market and investors. They are in direct contact with the investors and can better understand the needs of the investors. Thus, through the subjective judgement of the subject expert, this research aims to provide rank to identified factors.

Study of Yu and Ting (2011) show the importance of AHP while selecting wealth management services. The authors adopted the AHP model to understand which factors influence customers' decisions while selecting wealth management services. Also, Ramasamy and Yeung (2003) investigates the relative importance of attributes for a financial advisor. However, this paper aims to identify factors which are relevant for an individual investor to invest in the equity market and then their relative importance. There are very few studies which focus on the individual investors' behavioural factors and their relative importance in general and especially for the Indian market.

Thus, this research paper has the below mentioned objectives:

1. To explore the factors that is considered by an equity investor before investing in the Indian stock market.

2. To determine the relative importance of identified factors by assigning weights (ranks) to them.

The paper has been divided into six sections. After the first section on the introduction, the second section is on the relevant literature review. The third section is on the data and methodology used in the paper. The findings have been discussed in the fourth section under Results. The fifth section compares the findings of the current paper with the earlier done studies under discussion section. The paper is concluded in the sixth section.

\section{Review of Literature}

\subsection{Participation in the Equity Market}

Previous studies on equity investments can be divided into the following two categories: studies' on investments in the stock market and studies on investment in equitylinked mutual funds. There are two categories of investors who invest in the capital market. One group of investors invests in stocks and others invest in equity-linked mutual funds. However, percentage of investors who invests in the equity market is quite less in India as compared to other countries [section 1] (Christelis, Georgarakos, \& Haliassos, 2013; Gardini \& Magi, 2007; Guiso \& Sodini, 2013; RBI, 2017). Both types of investors have a different 
criterion for making investment decisions. However, this study does not primarily focus on the factors which drive participation in equity market instead on the relative importance of factors for the investments in equity or equity-linked mutual funds.

Many historians have discussed the importance of certain factors in investment decision making. Bashir et al. (2013) identify five main factors for investments in stock markets: 1) self-image; 2) neutral information; 3) accounting information; 4) personal financial needs; and 5) advocate recommendation. However, the authors did not discuss the relative importance of the factors. Similarly, Almenberg \& Dreber (2015) highlight the role of gender and financial literacy as relevant factors for stock market participation. Also, Jagannathan and Kocherlakota (1996) show age as an important factor for participation in the stock market. According to Sahi, Dhameja and Arora (2012), psychographic factors emerged as the most significant factors for predicting Indian investors preferences.

Several authors have advocated financial literacy as an essential factor which influences the investment decision of equity investors. Clark-Murphy and Soutar (2004) show that in Australia, the most relevant factor for stock market participation is linked to financial awareness. Also, Guiso and Jappelli (2005) exhibit that participation in the stock market or mutual funds are associated with financial knowledge Another study by Van Rooij, Lusardi and Alessie (2011) asserts that financial literacy is strongly associated with the decisions to invest in equity. Financial products knowledge and product involvement hold significant consideration over investment intention (Lim, Soutar \& Lee, 2016). Moreover, Lim, Soutar, and Lee (2016) also share that product knowledge reduces the risk aversion of the investors of stocks and equity-linked mutual funds.

Extending the concept of financial literacy given by Van Rooij, Lusardi and Alessie (2011); Kaur and Kaushik (2016) present similar findings for equity-linked mutual fund investments. They exhibit that awareness about the financial products, and socioeconomic characteristic are important factors for the investor investing in equity mutual funds. Barber, Huang and Odean (2016)'s work endorses the earlier findings on financial literacy for investments in mutual funds. Furthermore, extending the work of Kaur and Kaushik (2016); Kaur (2018) explains that knowledge and perception of investors also matter for investors before they invest in mutual funds. Guiso, Sapienza and Zingales (2008) suggest a lack of confidence in the capital market as one of the essential factors for limited participation in the stock market.

Obamuyi (2013) argue that religion does not have any influence over investment decision. However, there is evidence that in specific cases, religion is one of the significant factors while investment decision making (Mohammed Kamil et al., 2018). Mohammed Kamil et al. (2018) provide evidence in support of the religious argument for investment in equity-linked mutual funds in Malaysia. Kaustia and Torstila (2011) find evidence that the personal value system governs investments in stocks. People may have an aversion to stocks due to their values. Sahi and Arora (2012); Shafi (2014) advocate that behavioural reasons are more important than any other factor for investing in the stocks.

As above mentioned studies focus on the individual traits of investors, there are studies which investigates the impact of company-specific factors. Obamuyi (2013) explores company-specific factors which matters to Nigerian equity investors. The author points out that the critical company-specific factors are the past performance of the companies, corporate actions and the possibility of a quick return. However, the least important factors are loyalty to the companies, opinion of the family members and expected losses in the other investments. In the same vein, Ahmad (2017) highlights return, stock marketability, financial condition, expected dividends, current economic indicators, past performance and broker recommendation as the important factors for investments into the stock market. Chawla (2014) demonstrate that tax-savings, growth, capital appreciation and past performance of the mutual fund scheme are the relevant factors for investments into equity-linked mutual funds. Ramasamy and Yeung (2003) show the importance of following three factors for investment in the equity-linked mutual funds: the size of the fund, past performance and cost of the transaction.

There are a few issues which also play its role in deciding about the NPS. Shareholders' activism is one among them (Shingade \& Rastogi, 2019). The issues related to the dividend income also has its own impact on the participation in the stock market (Pinto and Rastogi, 2019, Pinto et al., 2019). Disclosure also has its role in 
NPS (Bhimavarapu \& Rastogi, 2020; Sharma, Rastogi \& Gupta, 2020). In addition to these, efficiency of the stock market also has its own role to play to sustain the interest of the investors in the stock market and in the determination of the stock prices (Patil \& Rastogi, 2019, $2020 \mathrm{a}, \mathrm{b})$.

However, there exists a plethora of literature concerning factors affecting participation in the equity market; none of the studies focuses on the relative importance of factors.

\subsection{Analytical Hierarchical Process (AHP): A Multifaceted Phenomenon}

AHP is a popular decision-making technique that has been utilised by several researchers for the relative ranking of factors. The literature review on AHP reveals prior utilisation of AHP in the field of Operational Research, General Management and Finance. Literature shows that the AHP method is multifaceted, not time- bound and can solve unconstrained problems.

For the current study, this paper focuses primarily on the application of AHP in financial constraints. Zopounidis (1999), applied AHP to ascertain the financial decisions of the organization for optimal funds allocation through experts subjective opinion. Yu and Ting (2011) adopted the AHP methodology to analyze the consumers choice while selecting the Wealth Management (WM) services. The author conducted a structured questionnaire survey and found that quality service offered, products and relative risk associated with them and the Image of the WM firm are few of the factors consumers would use in deciding the particular WM services.

Studies of Saraoglu and Detzler (2002); Perez-gladish and M'Zali Bouchra (2010) show the importance of AHP in ranking mutual funds on certain financial and nonfinancial factors. Saraoglu and Detzler (2002) applied AHP in selecting mutual funds by taking into consideration the preferences of individual investors. Similarly, Perezgladish and M'Zali Bouchra (2010) have also given an AHP approach to rank the MFs. They proposed to use the AHP for assessing the socially responsible behaviour of the mutual funds. However, these studies have not considered individual-specific factors in their ranking. They have deemed only financial factors and socially responsible factors in their research. Thus, initially, our research aims to identify factors affecting equity investment decision and further rank them according to their relative importance.

From the above literature, it can be synthesised that a large and growing body of literature has investigated factors that influence the investment decisions of institutional investors. However, their lies a subsequent research gap pertaining to the Indian equity investors. There are only a few studies which caters the perceptions of Indian investors. Also, the authors of this paper could not find any significant articles on the relative ranking of the factors for investments in equity. The relative ranking is a vital research gap, which is filled by the present study.

\section{Data and Methodology}

\subsection{Data}

A structured questionnaire survey was taken by 311 respondents who have prior experience of investing in the equity market and equity-based mutual funds. The statements used in the questionnaire are listed in Table 1. Variable to case method is used to establish an adequate

Table 1. Matrix (rotated component)

\begin{tabular}{|c|c|c|c|c|c|c|}
\hline Items & $\mathbf{1}$ & $\mathbf{2}$ & $\mathbf{3}$ & $\mathbf{4}$ & $\mathbf{5}$ & $\mathbf{6}$ \\
\hline $\begin{array}{c}\text { The returns by investing in the } \\
\text { company's shares has been made } \\
\text { aware to me. }\end{array}$ & .703 & & & & & \\
\hline $\begin{array}{c}\text { Only after a close investigation } \\
\text { of the financial aspects of the } \\
\text { company I would invest in their } \\
\text { stocks }\end{array}$ & .684 & & & & & \\
\hline
\end{tabular}




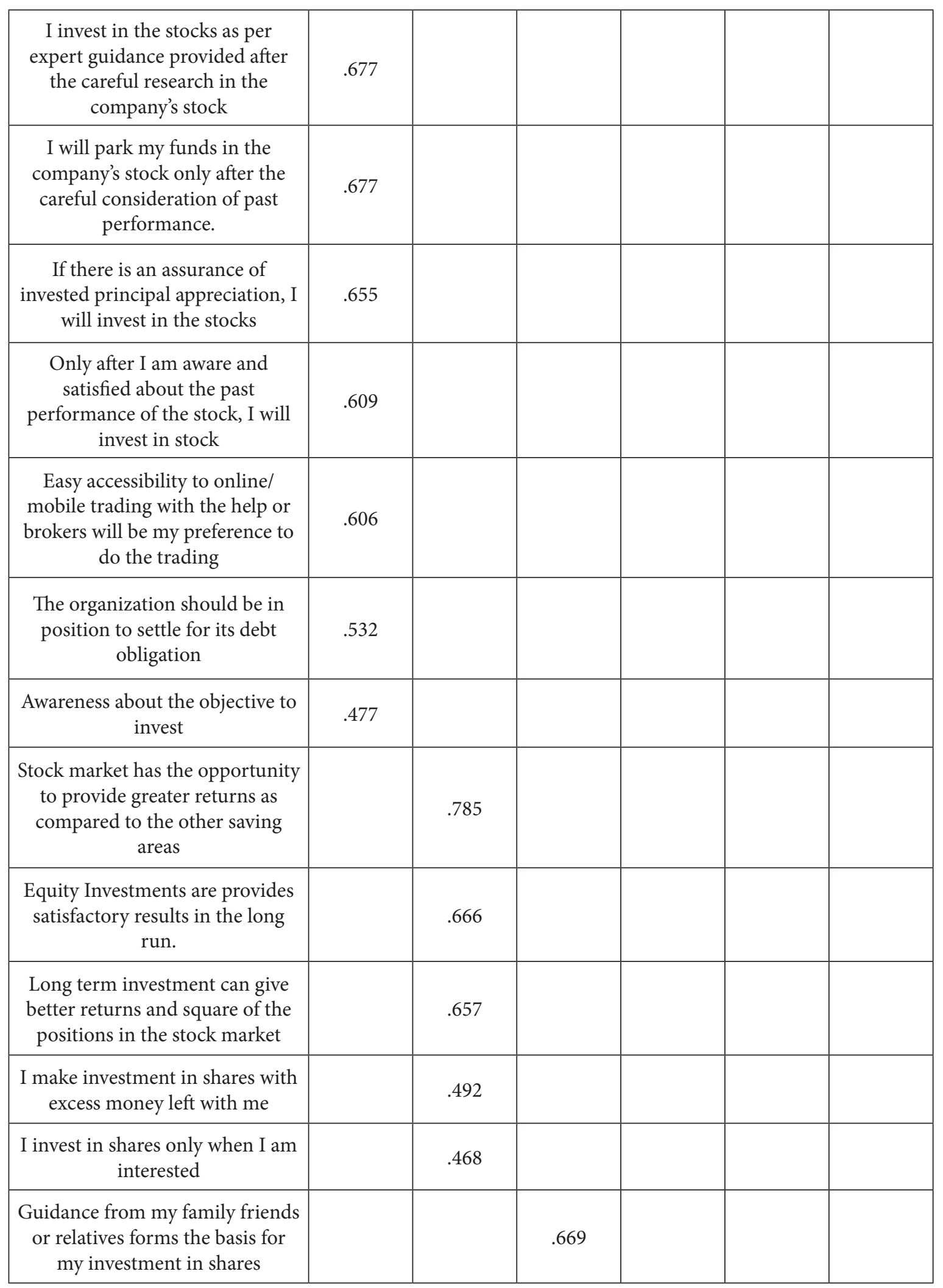




\begin{tabular}{|c|c|c|c|c|c|c|}
\hline I invest in shares by getting loans & & & 609 & & & \\
\hline $\begin{array}{l}\text { I invest in stocks when there is } \\
\text { an upward trend in the market }\end{array}$ & & & .580 & & & \\
\hline $\begin{array}{c}\text { Financial advisor suggestion is } \\
\text { the base for me to invest in the } \\
\text { capital market }\end{array}$ & & & .546 & & & \\
\hline $\begin{array}{l}\text { I am aware that dividends are } \\
\text { tax-free. }\end{array}$ & & & & .664 & & \\
\hline $\begin{array}{l}\text { Equity investments involves } \\
\text { higher risk than debt investment }\end{array}$ & & & & .587 & & \\
\hline $\begin{array}{l}\text { I am aware about the risk } \\
\text { involved in investing in equity }\end{array}$ & & & & .541 & & \\
\hline $\begin{array}{l}\text { I am aware about losing part or } \\
\text { full investment when the returns } \\
\text { from investment are greater than } \\
\text { expected }\end{array}$ & & & & & .712 & \\
\hline $\begin{array}{l}\text { Media and Magazines forms the } \\
\text { base for me to invest in shares of } \\
\text { the company }\end{array}$ & & & & & .607 & \\
\hline $\begin{array}{l}\text { I invest in stock market when the } \\
\text { market is in a downward trend. }\end{array}$ & & & & & & .668 \\
\hline $\begin{array}{l}\text { I invest in shares with a part of } \\
\text { my income }\end{array}$ & & & & & & .522 \\
\hline Eigen Values & 4.781 & 3.045 & 1.976 & 1.911 & 1.898 & 1.723 \\
\hline$\%$ of Variance Explained & 20.93 & 15.15 & 6.586 & 6.370 & 6.327 & 5.743 \\
\hline $\begin{array}{c}\text { \% Cumulative Variance } \\
\text { Explained }\end{array}$ & 20.93 & 36.08 & 42.67 & 49.04 & 55.37 & 61.11 \\
\hline Cronbach Alpha & .863 & .751 & .642 & .657 & .617 & .655 \\
\hline
\end{tabular}

sample size in the current study. For the 25-statement, a sample size of 311 is sufficient using a 1:10 ratio (Arrindell \& Van der Ende, 1985). Respondents were identified through convenient sampling. 30 Equity fund experts took another survey for AHP (Saaty, 2004) and subsequently, AHP methodology was applied.

\subsection{Methodology}

The methodology used in the analysis of the paper is twopronged. In the first step, Exploratory Factor Analysis (EFA) is performed on the given data set. In the literature, EFA is used generously (Rastogi \& Ragabiruntha, 2018). In the second step, AHP is applied to the identified factors to rank them. 


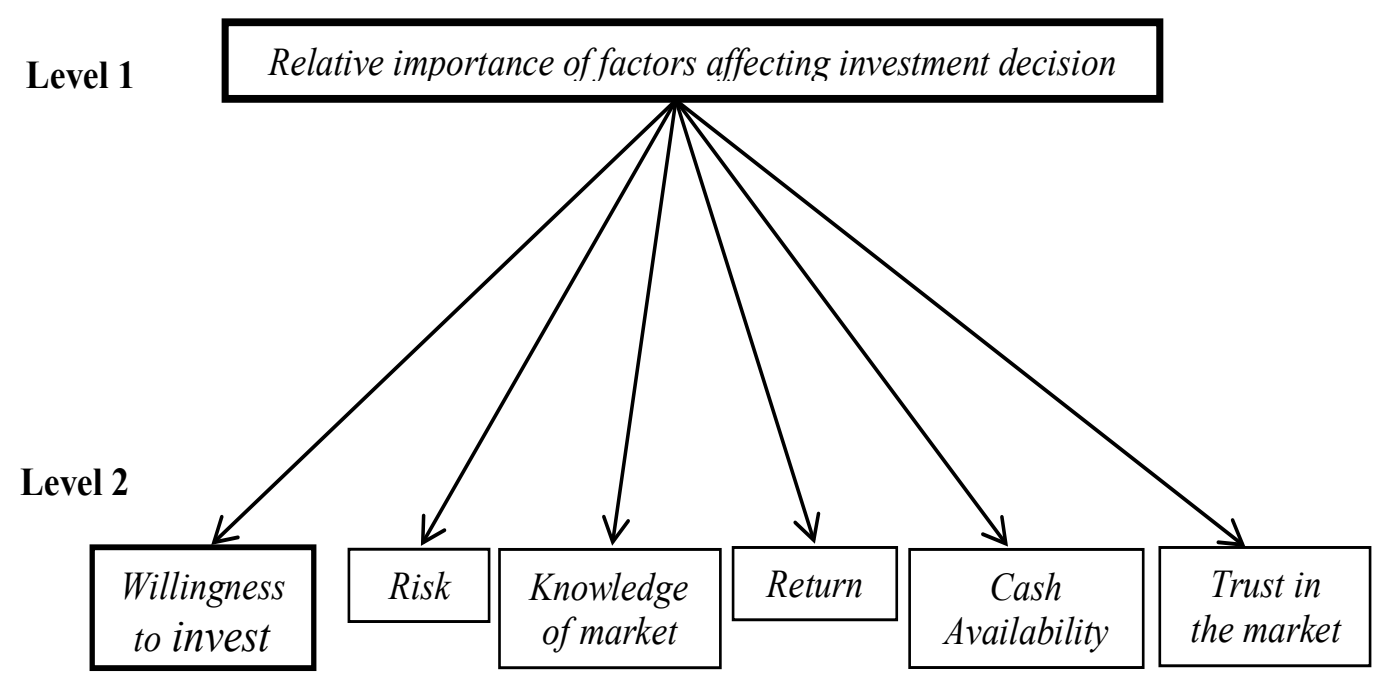

Figure 2. The hierarchical structure of equity investment decision.

Decision making is not just an art but science too. AHP enables group decision makers to consider complex factors in unstructured situations simultaneously. It further helps them to categorise and prioritise based on one's own objective, experience, and knowledge. The input to the AHP system is collective subjective judgement and outcome is summary of weighted priorities in the form of collective decision (Saaty, 1994).

AHP has two-step approach. The similar thing has been done in the current. The process of decision makking in AHP approach is depicted in Figure 2. In the beginning of the AHP process, the objective is described that to identify the most relvant factor for investments in the equity market by the investors. Six main factors that are identified using EFA are shown at level 2. There is no sub-criterion. Thus as suggested by Saaty and Peniwati (2013), the following steps were undertaken:

- Devise a solution to the identified problem which is in the form of a hierarchy which constitutes the decision goal, different criteria to seek different alternatives and ways to achieve it.

- Use paired comparison method in order to prioritise.

- The evaluations achieved are then converted to numerical values with the help of AHP and compared with the entire range of the problem.

- Check the consistency of the outcomes.
- Based on the results of the process to identify the final decision.

\section{Results}

\subsection{Exploratory Factor Analysis (EFA)}

The authors of this paper employed EFA, using SPSS (24) software. Both pre-investigation measures for EFA: KMO and Bartlett's test are sustaining in the current study. KMO sampling adequacy value is .832 and Bartlett's test is significant. When the reliability of the constructs was assured, for extraction of factors PCM is used. It was found that six factors have Eigen value more than 1 . After factor rotation, factor loadings were reported. The varimax method was applied for factor rotation. Factor loadings were higher than .45 .

Using EFA, six factors are identified. Knowledge, return, trust, risk, willingness to invest and availability of cash are the identified factors. They cumulatively explained $61.11 \%$ of the variance.

\subsection{Result of Analytical Hierarchical Process (AHP)}

In this research study, 30 Equity market experts were interviewed for their opinion in ranking Equity Funds based on the six factors derived through EFA. 
Table 2. Pair-wise comparison matrix for investments using expert judgements

\begin{tabular}{|c|c|c|c|c|c|c|}
\hline & KW & RT & TS & RK & WTI & CA \\
\hline KW & 1.00 & 7.00 & 3.00 & 5.00 & $1 / 3$ & $1 / 3$ \\
\hline RT & $1 / 7$ & 1.00 & 1.00 & 1.00 & $1 / 3$ & $1 / 3$ \\
\hline TS & $1 / 3$ & 1.00 & 1.00 & 1.00 & $1 / 3$ & $1 / 3$ \\
\hline RK & $1 / 5$ & 1.00 & 1.00 & 1.00 & $1 / 3$ & $1 / 3$ \\
\hline WTI & 3.00 & 3.00 & 3.00 & 3.00 & 1.00 & 1.00 \\
\hline CA & 3.00 & 3.00 & 3.00 & 3.00 & 1.00 & 1.00 \\
\hline
\end{tabular}

Note: KW is Knowledge. RT is Return. TS is trust. RK is risk. WTI is willingness to invest. CA is cash availability.

Table 3. Priority vector of factors matrix

\begin{tabular}{|c|c|c|c|c|c|c|c|}
\hline & KW & RT & TR & RK & WTI & CA & $\begin{array}{c}\text { Priority } \\
\text { Vector }\end{array}$ \\
\hline KW & 0.1303 & 0.4375 & 0.2500 & 0.3571 & 0.1000 & 0.1000 & 0.2292 \\
\hline RT & 0.0186 & 0.0625 & 0.0833 & 0.0714 & 0.1000 & 0.1000 & 0.0726 \\
\hline TR & 0.0434 & 0.0625 & 0.0833 & 0.0714 & 0.1000 & 0.1000 & 0.0768 \\
\hline RK & 0.0261 & 0.0625 & 0.0833 & 0.0714 & 0.1000 & 0.1000 & 0.0739 \\
\hline WTI & 0.3908 & 0.1875 & 0.2500 & 0.2143 & 0.3000 & 0.3000 & 0.2738 \\
\hline CA & 0.3908 & 0.1875 & 0.2500 & 0.2143 & 0.3000 & 0.3000 & 0.2738 \\
\hline
\end{tabular}

Note: KW is Knowledge. RT is Return. TS is trust. RK is risk. WTI is willingness to invest. CA is cash availability.

Saaty (1980) gave a fundamental scale of absolute numbers (Annexure: Table A1) which is currently employed in this study to formulate comparison matrix (Table 2). A pair-wise comparison is done as prescribed. A formula $\left(\mathrm{n}^{\star}(\mathrm{n}-1) / 2\right)$, as discussed is also deployed in the paper. In the formula, $\mathrm{n}$ stands for factors. This formula helps in deciding the how many times, the comparison is supposed to be done.
After this step, a comparison matrix is formed based on numerous factors. If the number of factors is $\mathrm{n}$, then the $n^{*} n$ matrix is formed. In the matrix, the diagonal elements are always kept as 1 , and the lower and upper matrix is formed based on the following condition.

- Being the judgement factor is left of 1 ; the actual judgement value is placed. 


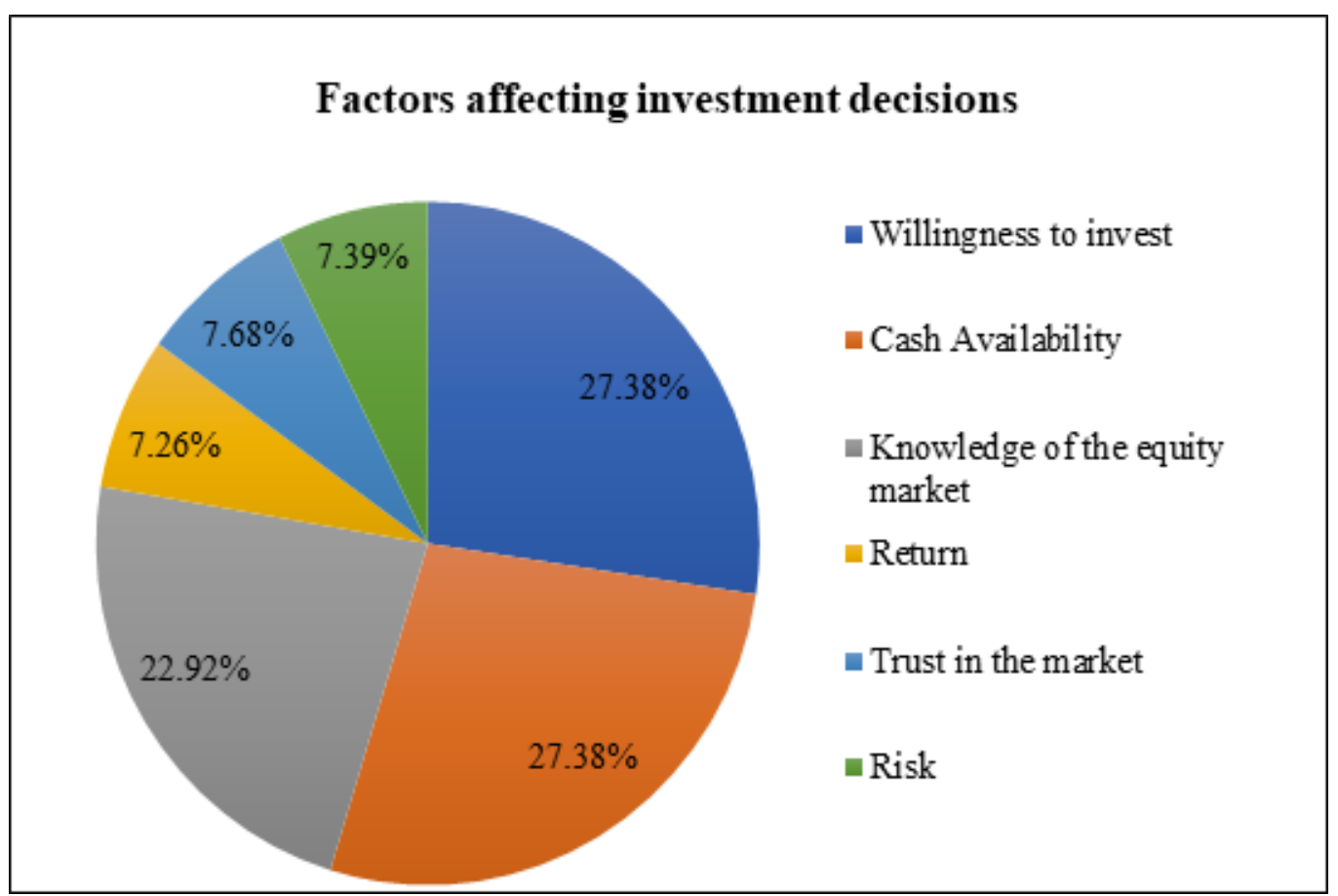

Source: Authors' Compilation.

Figure 3. Relative importance of factors affecting the investment decision.

- Being the judgment factor is right of 1 ; the reciprocal value is placed.

- By placing the reciprocal values of the upper matrix, the lower matrix is formed.

After the matrix is formulated, the principal Eigenvector is calculated. Each element of a column is added to obtain a column-wise sum. Further, each element is divided by its column sum. By averaging the value of each row, the Eigenvector is generated.

Table 3, it can be determined that for individual investors; 'willingness to invest' and 'cash availability' are selected. Both have been considered as most important factors for equity investments. Both factors hold equal weight-age for an investor. The second most important factor is 'knowledge of the stock market', while 'return' is the least important criteria. This shows the dominance of behavioural finance theory in the Indian equity market. A percentage of priority vectors are indicated in Figure 3.

According to Saaty (1980), a consistency ratio of 0.10 is considered acceptable. For this research Consistency index is 0.0974 and Random Consistency Index is 1.24. The values give the consideration that the analysis is consistent and adequate (Kim and Mueller, 1978; Nunnally, 1967).

\section{Discussion}

According to the classical wealth maximisation, it was assumed that investors are rational human beings and their investment strategies are considerably based on risk-return analysis (Markowitz, 1952). However, certain phenomenon has remained unexplained including non-participation in the equity market (Rastogi, 2014). Consequently, with the emergence of behavioural finance, it was argued by researchers that while making an investment decision, investors do not behave in accordance with the conventional financial theories and show irrational and emotional behaviour.

Specific experiments with people have revealed that what people do differs from the theoretical considerations (Saaty, 1994). The finding of our research supports the notion of behavioural finance and thereby challenges the actualisation of conventional financial theory. In the result, it was observed that willingness to invest 
in the stock market and knowledge of investing in the stock market supersedes the risk and return factor. This result profoundly challenges the assumptions of wealth maximisation theory. As evident with the findings of this paper, Indian stock market sentiments can be explained by behavioural finance theories. While making an investment decision, among all factors, behavioural factors hold equal importance for an investor (Sahi \& Arora, 2012).

\subsection{Policy Implication of the Findings of the Current Paper}

Financial markets are based on sentiments; the present study will help the policy makers to understand which factors can boost the positive sentiments in the investors. As the study unveils that willingness of the investor is ranked first, this is further linked to the high satisfaction level of the investors. A satisfied investor will facilitate more investors and this, in turn, will improve liquidity and the volume of the stock markets.

The study lays further emphasis on the investor's education programs, as 'knowledge' is also one of the leading factors to the growth in the investors' participation. The view is supported by Sahi and Arora (2012). The authors assert that individuals who have better financial knowledge drive more satisfaction from their investment. This lightens the fact that developing countries where investor participation is less should come up with more reforms and financial awareness programs, to persuade investors to invest more in stocks.

Also, a financial advisor could draw a better financial training program, which would make investors more confident in their decision. A confident and knowledgeable investor would be more involved with investment decisions. The government should also work on the structural efficiency of the capital markets to increase the trust among investors.

\subsection{Contribution and Significance of the Current Paper}

Current research significantly contributes to the existing body of literature of the stock market involvement. Apart from deriving the relevant factors of stock market participation through EFA, the study ranks these factors in the order of their preference by using AHP methodology which is the significant contribution of the research. Although some research has been carried out on the factors relevant for an investor, no single study exists which provides the relative importance of factors through the application of AHP. This paper makes a novel contribution by applying ranks to behavioural and financial factors of the investment decision process.

With the emergence of behavioural finance, investment process cannot solely rely on financial factors. To get a more realistic understanding, it is essential for authorities to include behavioural factors into consideration. Thus, for a fund advisor, it is crucial to have a complete picture of individual investor preferences before giving any financial advice. A fund manager can better serve the investor need if he can understand the selection criterion of an investor. Also, the factors identified would help in designing better marketing strategies.

\section{Conclusion and Limitations}

This paper seeks to identify factors that are considered relevant by individual investors while investing in the equity market. Our survey of 311 existing equity investors gave insight into six factors that are considered by equity investors before investing in the equity market. The implication of EFA reveals that Knowledge of the equity market, Risk of investing, Returns gained by investing, Availability of cash, Willingness to invest and Trust of investing in the market are the relevant aspects that play a significant role in the investment decisions of Indian equity investors.

The other relevant part of this research is the implication of AHP. The factors identified through EFA were given ranks according to their relative importance. Financial experts undertook the survey. The results of AHP revealed that inclination to invest in the capital market and cash availability hold equal weight-age followed by knowledge of the equity market. Return, risk and trust of investing in the market holds a relatively less vital role in the decision making of an equity investor. This result indicates the importance of inclination to invest in the capital market. According to AHP result, having an appropriable amount of cash is not the sole important factor concerning investment, but an investor's willingness to invest the same is also equally important. The other conclusion of this analysis reveals 
that behavioural finance supersedes the traditional theory (wealth maximisation theory). An investor does not base his decision solely on the risk and return analysis but also give preference to other factors as well, such as having appropriable knowledge of the market and trust in the equity market.

With the low investment rate in the Indian equity market, this research will serve a meaningful purpose. The factors identified would provide a benchmark for the individual who is looking forward to investment in equity market. The identified factors would give novice investors guidance on factors that they should look upon before stepping into the equity market. Also, fund managers who serve as investment advisors can better analyse the need of an equity investor and can serve them accordingly.

The scope of this paper is restricted to the equity market and equity-based mutual funds. Future research can be extended to different investment avenues such as debt market, commodity market, etc. across different demographical and geographical locations.

\section{References}

Ahmad, S. (2017). Factors influencing Individual investors's behaviour: An empirical study of Pakistan financial markets, Journal of Business and Financial Affairs, 6(4), 1-8. https://doi.org/10.4172/2167-0234.1000297.

Almenberg, J., \& Dreber, A. (2015). Gender, stock market participation and financial literacy, Economics Letters, 137, 140-142. https://doi.org/10.1016/j.econlet.2015.10.009.

Arrindell, W.A., \& Van der Ende, J. (1985). An empirical test of the utility of the observations-to-variables ratio in factor and components analysis, Applied Psychological Measurement, 9(2), 165-178. https://doi. org/10.1177/014662168500900205.

Barber, B.M., Huang, X., \& Odean, T. (2016). Which factors matter to investors? Evidence from mutual fund flows, The Review of Financial Studies, 29(10), 2600-2642. https://doi. org/10.1093/rfs/hhw054.

Bashir, T., Azam, N., Butt, A.A., Javed, A., \& Tanvir, A. (2013). Are behavioral biases influenced by demographic characteristics and personality traits? Evidence from Pakistan, European Scientific Journal (ESJ), 9(29), 37-44.

Bhimavarapu, V.M., \& Rastogi, S. (2020), Valuation of Transparency-A Systematic Literature Review Paper, Test Engineering and Management, 83, 9092-9102.
Chawla, D. (2014). An empirical analysis of factors influencing investment in mutual funds in India, Global Business Review, 15(3), 493-503. https://doi.org/10.1177/0972150914535136.

Christelis, D., Georgarakos, D., \& Haliassos, M. (2013). Differences in portfolios across countries: Economic environment versus household characteristics, Review of Economics and Statistics, 95(1), 220-236. https://doi. org/10.1162/REST_a_00260.

Clark-murphy, M., \& Soutar, G.N. (2004). What individual investors value: Some Australian evidence, Journal of Economic Psychology, 25, 539-555. https://doi.org/10.1016/ S0167-4870(03)00056-4.

Dimitrios, I.M. (2007). Investors' behaviour in the Athens Stock Exchange (ASE), Journal of Accountancy, 120(6), 67-72.

Engel, J.F., Kollat, D.T., \& Blackwell, R.D. (1968). Consumer Behaviour. New York: Holl, Rienard and Winston.

Gardini, A., \& Magi, A. (2007). Stock market participation: new empirical evidence from Italian households' behaviour, Giornale degli Economisti e Annali di Economia, 66,(1), 93.

Guiso, L., \& Jappelli, T. (2005). Awareness and stock market participation, Review of Finance, 9(4), 537-567. https://doi. org/10.1007/s10679-005-5000-8.

Guiso, L., Sapienza, P., \& Zingales, L. (2008). Trusting the stock market, The Journal of Finance, 63(6), 2557-2600. https:// doi.org/10.1111/j.1540-6261.2008.01408.x.

Guiso, L., \& Sodini, P. (2013). Household finance: An emerging field, Handbook of the Economics of Finance, 2, 1397-1532. https://doi.org/10.1016/B978-0-44-459406-8.00021-4.

Jagannathan, R., \& Kocherlakota, N. R. (1996). Why should older people invest less in stocks than younger people, Federal Reserve Bank of Minneapolis Quarterly Review, 20, 11-20. https://doi.org/10.21034/qr.2032.

Jain, S., \& Gangopadhyay, A. (2012). Analysis of equity based mutual funds in India, OSR Journal of Business and Management (IOSRJBM), 2(1), 1-4. https://doi. org/10.9790/487X-0210104.

Kaur, I. (2018). Mutual fund investor's behaviour towards information search and selection criteria: Do knowledge and perception about mutual funds matter? Qualitative Research in Financial Markets, 10(4), 395-414. https://doi. org/10.1108/QRFM-09-2017-0084.

Kaur, I., \& Kaushik, K.P. (2016). Determinants of investment behaviour of investors towards mutual funds, Journal of Indian Business Research, 8(1), 19-42. https://doi. org/10.1108/JIBR-04-2015-0051.

20. Kaustia, M., \& Torstila, S. (2011). Stock market aversion? Political preferences and stock market participation, Journal of Financial Economics, 100(1), 98-112. https://doi. org/10.1016/j.jfineco.2010.10.017. 
Kim, J.O., \& Mueller, C.W. (1978). Factor analysis: Statistical methods and practical issues (No. 14), Sage. https://doi. org/10.4135/9781412984256.

Lim, K.L., Soutar, G.N., \& Lee, J.A. (2016). Factors Affecting Investment Intentions: A Consumer Behaviour Perspective. In: Financial Literacy and the Limits of Financial Decision Making, Harrison T, Cham: Palgrave Macmillan; p. 201223. https://doi.org/10.1007/978-3-319-30886-9_10. PMCid:PMC5104843.

Markowitz, H. (1952). Portfolio selection, The Journal of Finance, 7(1), 77-91. https://doi.org/10.1111/j.1540-6261.1952. tb01525.x, https://doi.org/10.2307/2975974.

Mohammed Kamil, N., Subramaniam, M., Ali, H.E., Musah, M.B., \& Alex, A. (2018). Factors influencing the selection of unit trust funds among Malaysian retail investors, Journal of Islamic Accounting and Business Research, 9(2), 155-170. https://doi.org/10.1108/JIABR-11-2015-0057.

Nunnally, Jum C. (1967), Psychometric Theory, 1st Ed., New York: McGraw-Hill.

Obamuyi, T.M. (2013). Factors influencing investment decisions in capital market: A study of individual investors in Nigeria, Organizations and Markets in Emerging Economies, 4(1), 141-161. https://doi.org/10.15388/omee.2013.4.1.14263.

Patil, A.C., \& Rastogi, S. (2019). Time-varying price-volume relationship and adaptive market efficiency: A survey of the empirical literature, Journal of Risk and Financial Management, 12(2), 1-18. https://doi.org/10.3390/ jrfm12020105.

Patil, A.C., \& Rastogi, S. (2020a). Multifractal analysis of market efficiency across structural breaks: Implications for the adaptive market hypothesis, Journal of Risk and Financial Management, 13(10), 1-18. https://doi.org/10.3390/ jrfm13100248.

Patil, A.C., \& Rastogi, S. (2020b). Multifractal analysis of timevarying market efficiency: Implications for adaptive market hypothesis, Test Engineering and Management, 83, 1664616660.

Perez-gladish, B., \& M'Zali Bouchra. (2010). An AHP-based approach to mutual funds social performance measurement Bouchra M Zali, International Journal of Multicriteria Decision Making, 1(1), 103-127. https://doi.org/10.1504/ IJMCDM.2010.033689.

Pinto, G., \& Rastogi, S. (2019). Sectoral analysis of factors influencing dividend policy: Case of an emerging financial market, Journal of Risk and Financial Management, 12(3), 110. https://doi.org/10.3390/jrfm12030110.

Pinto, G., Rastogi, S., Kadam, S. \& Sharma, A. (2019). Bibliometric study on dividend policy, Qualitative
Research in Financial Markets, 12(1), 72-95. https://doi.org/10.1108/QRFM-11-2018-0118.

Ramasamy, B., \& Yeung, M.C.H. (2003). Evaluating mutual funds in an emerging market: Factors that matter to financial advisors, International Journal of Bank Marketing, 21(3), 122-136. https://doi.org/10.1108/02652320310469502.

Rastogi, S. (2014a). The financial crisis of 2008 and stock market volatility-analysis and impact on emerging economies pre and post crisis, Afro-Asian Journal of Finance and Accounting, 4(4), 443-459. https://doi.org/10.1504/ AAJFA.2014.067017.

Rastogi, S. (2014b). Investor apathy to stock market: A study using discriminant analysis, Abhigyan, 32(2), 1-14.

Rastogi, S., \& Ragabiruntha, E. (2018). Financial inclusion and socioeconomic development: Gaps and solution, International Journal of Social Economics, 45(7), 1122-1140. https://doi.org/10.1108/IJSE-08-2017-0324.

RBI. (2017). Handbook of Statistics on Indian Economy. Reserve Bank of India.

Ritter, J.R. (2003). Behavioral finance, Pacific-Basin Finance Journal, 11(4), 429-437. https://doi.org/10.1016/S0927$538 \mathrm{X}(03) 00048-9$.

Saaty, T.L. (1980). The Analytic Hierarchy Process: Planning, Priority Setting, Resource Allocation. New York: McGrawHill.

Saaty, T.L. (1994). How to make a decision: The analytic hierarchy process, Interfaces, 24(6), 19-43. https://doi. org/10.1287/inte.24.6.19.

Saaty, T.L. (2004). Decision making - the analytic hierarchy and network processes (AHP / ANP), Journal of Systems Science and Systems Engineering, 13(1), 1-35. https://doi. org/10.1007/s11518-006-0179-6, https://doi.org/10.1007/ s11518-006-0151-5.

Saaty, T.L., \& Peniwati, K. (2013). Group Decision Making: Drawing Out and Reconciling Differences. RWS publications.

Sahi, S.K., \& Arora, A.P. (2012). Individual investor biases: A segmentation analysis, Qualitative Research in Financial Markets, 4(1), 6-25. https://doi. org/10.1108/17554171211213522.

Sahi, S.K., Dhameja, N., \& Arora, A.P. (2012). Predictors of preference for financial investment products using CART analysis, Journal of Indian Business Research, 4(1), 61-86. https://doi.org/10.1108/17554191211206807.

Saraoglu, H., \& Detzler, M.L. (2002). A sensible mutual fund selection model, Financial Analysts Journal, 58(3), 60-72. https://doi.org/10.2469/faj.v58.n3.2538.

Shafi, M. (2014). Determinants influencing individual investor behavior in stock market: A cross country research 
survey, Nigerian Chapter of Arabian Journal of Business and Management Review, 2(1), 60-71. https://doi. org/10.12816/0003720.

Sharma, A., Rastogi, S. \& Gupta, N. (2020). Financial efficiency of non-banking financial companies-microfinance institutions: A data envelopment analysis, Test Engineering and Management, 83, 9080-9091.

Shingade, S.S., \& Rastogi, S. (2019). Shareholders' activism and firm performance: A review of literature, Indian Journal of Commerce and Management Studies, 10(2), 22-30. https:// doi.org/10.18843/ijcms/v10i2/04.

Solomon, M.R. (1999). Consumer Behavior: Buying, having and being, Fourth Ed. Upper Saddle River, NJ: PrenticeHall.
Van Rooij, M., Lusardi, A., \& Alessie, R. (2011). Financial literacy and stock market participation, Journal of Financial Economics, 101(2), 449-472. https://doi.org/10.1016/j. jfineco.2011.03.006.

Yu, V.F., \& Ting, H.I. (2011). Identifying key factors affecting consumers' choice of wealth management services: An AHP approach, Service Industries Journal, 31(6), 929-939. https://doi.org/10.1080/02642060903078750.

Zopounidis, C. (1999). Multicriteria decision aid in financial management, European Journal of Operational Research, 119(2), 404-415. https://doi.org/10.1016/S03772217(99)00142-3.

\section{Annexure}

Table A1. The Fundamental scale of absolute numbers

\begin{tabular}{|c|c|c|}
\hline $\begin{array}{l}\text { Intensity of } \\
\text { Importance }\end{array}$ & Definition & Explanation \\
\hline 1. & Equal importance & $\begin{array}{l}\text { Both activities are equal } \\
\text { contributors to the objective }\end{array}$ \\
\hline 2. & Weak or slight & \\
\hline 3. & Moderate importance & $\begin{array}{l}\text { It occurs when the Experience } \\
\text { and judgment of one activity is } \\
\text { slightly preferred over another }\end{array}$ \\
\hline 4. & Moderate plus & \\
\hline 5. & Strong importance & $\begin{array}{c}\text { Is reflected when the Experience } \\
\text { and judgment of one activity is } \\
\text { strongly in favor as compared to } \\
\text { other }\end{array}$ \\
\hline 6. & Strong plus & \\
\hline 7. & $\begin{array}{l}\text { Very strong or demonstrated } \\
\text { importance }\end{array}$ & $\begin{array}{l}\text { A dominant practice is reflected } \\
\text { when an activity is strongly } \\
\text { chosen over another activity. }\end{array}$ \\
\hline 8. & Very, very strong & \\
\hline 9. & Extreme importance & $\begin{array}{l}\text { The evidence favoring one activity } \\
\text { over another is of the highest } \\
\text { possible order of affirmation }\end{array}$ \\
\hline
\end{tabular}




\begin{tabular}{|c|c|c|}
\hline $\begin{array}{c}\text { Reciprocals of } \\
\text { above }\end{array}$ & $\begin{array}{c}\text { If activity i has one of the above } \\
\text { nonzero number assigned to it } \\
\text { when compared with activity j, } \\
\text { then } \mathrm{j} \text { has the reciprocal value } \\
\text { when compared with } \mathrm{i}\end{array}$ & A realistic assumption \\
\hline Rational & Ratios arising from the scale & $\begin{array}{c}\text { A forced consistency by } \\
\text { converting numerical values into } \\
\text { a matrix format }\end{array}$ \\
\hline
\end{tabular}

Note: Values 2,4,6,8 are Intermediate values between adjacent scale values which are used when compromised is needed.

Source: Saaty (1980). 